\title{
Hymenaphorura uzicensis, a new cave species of springtails (Onychiuridae: Collembola) from West Serbia
}

\author{
Božidar P. M. Ćurčić, Luka R. Lučić, Srećko B. Ćurčić, \& Nina B. Ćurčić \\ Ćurčić, B. P. M., Lučić, L. R., Ćurčić, S. B. \& Ćurčić, N. B. 2005: Hymena- \\ phorura uzicensis, a new cave species of springtails (Onychiuridae: Collembola) \\ from West Serbia. - Entomol. Fennica 16: 175-178. \\ A new species of the collembolan family Onychiuridae, Hymenaphorura uzi- \\ censis n. sp., has been described from the Potpećska Pećina Cave, nr. Užice, West \\ Serbia. It is phenetically closest to Hymenaphorura polonica Pomorski. This \\ new taxon is endemic and probably restricted only to its cave habitat. \\ B. P. M. Curčić, L. R. Lučić, S. B. Curčić and N. B. Curčić, Institute of Zoology, \\ Faculty of Biology, University of Belgrade, Studentski Trg 16, 11000 Belgrade, \\ Serbia and Montenegro; E-mail: bcurcic@bf.bio.bg.ac.yu
}

Received 2 January 2003, accepted 3 August 2004

\section{Introduction}

Bogojević (1968) has summarized studies on the Onychiuridae of Serbia. Besides including all the then-known species of the former Yugoslavia (including Slovenia, Croatia, Bosnia and Herzegovina, Montenegro, and FYROM), the list also contained a presentation of the state of the systematic knowledge.

Since then, collembolan taxonomy has been revised considerably: new criteria of taxonomic description have been introduced, many new species described, and the views on the systematics of the family as a whole have changed. Also, many species previously unknown have been recorded from Serbia (Ćurčić \& Lučić 1997, 1998, 1999).

Of the 220 species of collembolans recorded in the former Yugoslavia (Bogojević, 1968), only seven epigean species of the genus Onychiurus Gervais have been found in Serbia. Subsequently, Ćurčić \& Lučić (1997, 1998, 1999) described four species new to science: Onychiurus pancici Ćurčić \& Lučić, $O$. trojan Curčić \& Lučić, $O$. ravanicae Curčić \& Lučić, and $O$. zloti
Curčić \& Lučić, all from caves in East Serbia.

Within the last years, Pomorski (1990, 1996, 1998) and Weiner (1996) have discussed the systematics of the Onychiuridae. There are currently two general concepts of taxonomic division. The first of them postulates the presence of only one genus, viz. Onychiurus, with a few subgenera, while the other advocates many genera grouped into several subfamilies or tribes. Both Pomorski (1996, 1998) and Weiner (1996) share the latter opinion.

We collected a sample of cave representatives of Hymenaphorura Bagnall in West Serbia in 2002. This genus has otherwise not been recorded in Serbia. The taxonomic status of the taxon, according to different specialists, has been varying in ranging the genus from a synonymy with Onychiurus to a distinctive tribe (Bagnall 1948, Gisin 1960, Pomorski 1998, 2001).

Our study of the newly collected species of Hymenaphorura has yielded that this taxon is new both to science and to the fauna in Serbia. As the habitat of Hymenaphorura species is normally rotting wood, it was interesting to find a member of this genus in an underground habitat. 

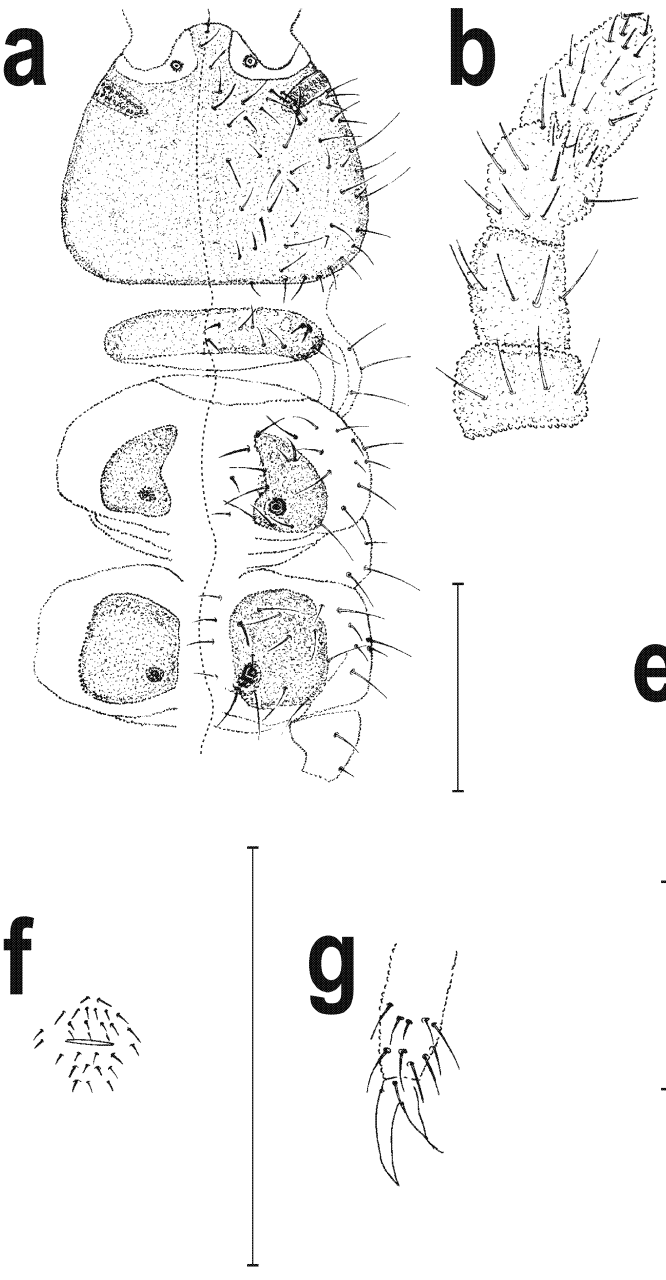

\section{Species description}

\section{Hymenaphorura Bagnall}

\section{Hymenaphorura uzicensis sp. $\mathrm{n}$.}

Material examined. Holotype $q, 4$ paratype $q q$ on slides (in gum-chloral medium), from the Potpećska Pećina Cave (captured by hand searching, below small rocks on the cave ground), near Užice, West Serbia, Serbia, 21.VIII.2002; coll. B. P. M. Ćurčić, S. B. Ćurčić, and B. M. Mitić. Type specimens (holotype: IZUB 2001, paratypes: IZUB 2002-5) are deposited in the collections of the Institute of Zoology, Faculty of Biology, University of Belgrade, Belgrade, Serbia.

Description. Female. Holotype $q$, body
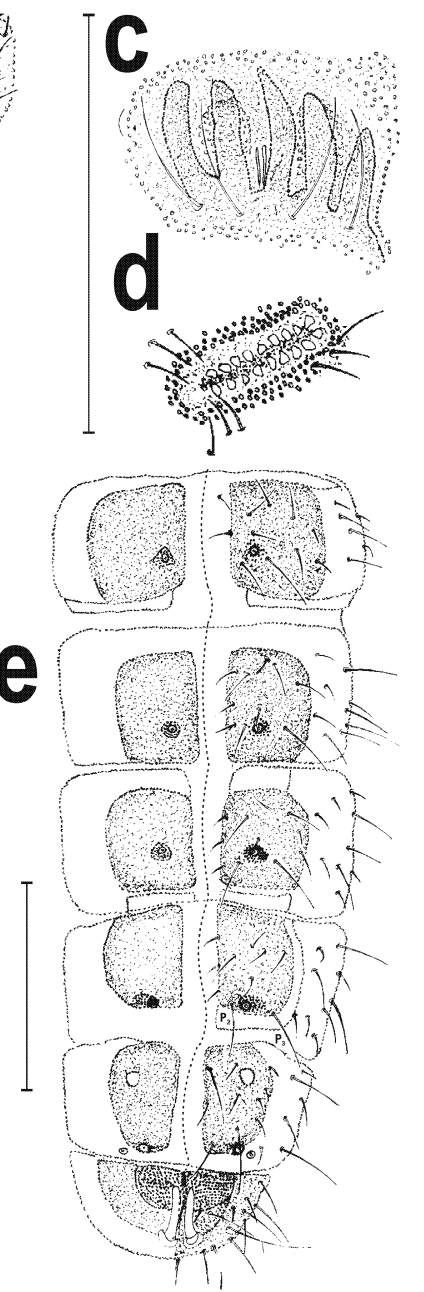

Fig. 1. Hymenaphorura uzicensis sp. n., holotype female. - a. Dorsal chaetotaxy: head and thoracical segments I-III. - b. Antenna. - c. Sense organ of antenna. $-\mathrm{d}$. Post-antennal organ (PAO). - e. Abdominal segments I-VI. - f. Genital plate. - g. Leg III. Scale bars $0.25 \mathrm{~mm}$.

length $1.78 \mathrm{~mm}$, body length of $q$ paratypes: 1.34 $\mathrm{mm}, 1.59 \mathrm{~mm}, 1.90 \mathrm{~mm}$, and $1.81 \mathrm{~mm}$. Colour in alcohol white. Body shape elongated, subcylindrical. Distinctive areas of variable granulation on dorsal side of body of C2 type (sensu Arbea \& Jordana 1994) (Fig. 1a). Usually 11-12 grains around each pseudocellus (Fig. 1a). Head longer than antennae. Antennal segments I-IV with 4, 5, 9, and 15 dorsal setae, respectively. Antennal segment lengths ratios: I : II : III : IV = $1: 1.2: 1.4: 2.6$ (Fig. 1b). Sensory organ of antennal segment III built of 5 papillae, 5 (rarely 4 ) setae, 2 sensory rods, and 2 granulated sense clubs (Fig. 1c). Antennal segments II and IV each with one latero-external microsensillum in the posterior half of each segment (Fig. 1b).

Postantennal organ (PAO) ellipsoid, in an 
elongated cuticular groove, with 17 simple tubercles (vesicles) parallel or oblique in relation to the longer axis of this organ (Fig. 1d).

Pseudocellar tergal formula (per demi-tergite): 10/011/11112 (Fig. 1a, e); ventral pseudocelli absent. Subcoxal pseudocelli absent, both laterally and ventrally. Parapseudocelli very difficult to distinguish.

Dorsal chaetotaxy as in Fig. 1a and 1e. Seta $d_{0}$ absent on the head. Macrochaetae distinct. On abdominal terga I-IV chaetae $\mathrm{p}_{3}>\mathrm{p}_{2}$ (Fig. 1e). Thorax II-III (chaetae $\mathrm{p}_{2}=\mathrm{p}_{3}$ ) without lateral microsensilla (Fig. 1a). Granular area on abdominal tergum $\mathrm{V}$ with $5+5$ more or less developed macrochaetae $\left(a_{1}, a_{4}, p_{1}, p_{2}, p_{4}\right)$ (Fig. 1e).

Ventral tube with $10+10$ setae. Furca entirely absent.

Female genital plate as in Fig. 1f.

Anal spines developed, inclined backwards (length $0.05 \mathrm{~mm}$ ) (Fig. 1e). Anal papillae separated basally. Claw length $0.06 \mathrm{~mm}$. Inner edge of claw 1.2 times as long as anal spines.

Tibiotarsi I, II, and III with 10 setae each (Fig. 1g). Femora I, II, and III with 8, 9, and 12 setae, respectively. Trochanters I, II, and III with 5, 4, and 5 setae, respectively. Subcoxae I, II, and III with 3,2 , and 1 long setae and 0,1 , and 1 short setae, respectively. Tarsal claws with no teeth. Empodium length $0.03 \mathrm{~mm}$. Empodial appendage with a basal lamella; tarsal claw almost twice as long as empodium (Fig. $1 \mathrm{~g}$ ).

Variability. Among female specimens examined, the number of setae in sensory organ of antennal segment III is variable (4 or 5).

Biology. To our knowledge, H. uzicensis inhabits a single cave in West Serbia.

Etymology. This species is named after its locality.

\section{Discussion}

The new species is phenetically close to Hymenaphorura polonica Pomorski, a species with Palaearctic distribution (Fjellberg 1998). The two species are similar in body size and both have dorsally the same number of pseudocelli (10/011/11112), the same number of grains around each pseudocellus (11-12), the similar structure of antennal sense organs and the same number of setae on ventral tube $(10+10)$. Both species are similar also in the form of the tarsal claws (without denticle) and the empodial appendage (with a basal lamella).

However, Hymenaphorura uzicensis sp. n. and $H$. polonica clearly differ by the PAO structure (17 vs. 10 lobes), type of granulation on dorsal side of body (C2 vs. D), in lateral microsensillae on thoracal tergites II and III (absent vs. present), in the absence/presence of subcoxal pseudocelli (absent vs. present), in trochanteral pseudocelli (absent vs. present), in the setation of subcoxae I, II, and III [with 3, 2, and 1 long setae and 0,1 , and 1 short setae vs. with one long seta and 3-6 shorter setae; sensu Fjellberg (1998)], and in the chaetotaxy of the granular area of tergite $\mathrm{V}$ (with $5+5$ macrochaetae vs. $1+1$ macrochaetae).

Deeleman-Reinhold (1978) and Ćurčić (1988) have suggested that during the Tertiary period the Proto-Balkan land may have had long periods of equatorial climate and may have been covered by tropical and subtropical forests. Early strains of photophobic, hygrophilic, and humicolous animals proliferated there in moist detritus. The large, probably rapid, climatic subversion at the end of the Miocene epoch (Hsü 1972, 1978) must have brought aridity to the Balkan Peninsula. Subsequently, with increasing humidity the Balkans became the main center of dispersion of different faunistic groups (including collembolans); this explains some close interrelationships between many local faunal elements inhabiting various areas of the Northern Mediterranean.

Among the main causes that have affected the history of cave collembolans in the Balkan Peninsula, one should emphasize the effects of the karstification process that took place progressively throughout its life span. Thus, some protoHymenaphorura forms may have evolved to compete successfully with new immigrants. The living conditions in caves have certainly changed, but in a manner to have provoked disappearance of the majority of relicts. Therefore, such changes have favoured the divergent differentiations of these cave collembolans.

The study of the cave collembolans of the Balkan karst has offered further evidence of their great ages and different origins. These species 
and genera, including Hymenaphorura, represent the vestiges of an old fauna that found shelter in the underground domain of the Balkans and its adjoining regions.

Acknowledgements. The authors appreciate the financial help from the Serbian Ministry for Science (Grant 1547), and the suggestions of S. Hopkin and J. C. S. Benito.

\section{References}

Arbea, J. I. \& Jordana, R. 1994: Quatro nuevas especies de la familia Onychiuridae de la Península Ibérica (Collembola, Poduromorpha). — Publ. Biol. Univ. Navarra Ser. Zool. 24: 39-59.

Bagnall, R. S. 1948: Contributions towards a knowledge of the Onychiuridae (Collembola - Onychiuroidea). IIII. - Ann. Mag. Nat. Hist. 11 (14): 217-226.

Bogojević, J. 1968: Catalogus Faunae Jugoslaviae. III/6. Collembola. - Cons. Acad. Sci. Rei Publ. Soc. Foed. Jugosl., Acad. Sci. Art. Slov., Ljubljana. 31 pp.

Ćurčić, B. P. M. 1988: Cave-dwelling pseudoscorpions of the Dinaric Karst. - Acad. Sci. Art. Slov., Classis IV: Hist. Nat.; Opera 26; Inst. Biol. Ioannis Hadži, Ljubljana. 191 pp.

Ćurčić, B. P. M. \& Lučić, L. R. 1997: Onychiurus (Protaphorura) zloti, a new endemic species of cave springtails (Onychiuridae, Collembola) from East Serbia, Yugoslavia. - Arch. Biol. Sci., Belgrade 49 (3-4): 35P-36P.

Ćurčić, B. P. M. \& Lučić, L. R. 1998: Two new cavedwelling species of Onychiuridae (Collembola) from Serbia, Yugoslavia. — Ent. Ber. 58 (4): 70-72.
Ćurčić, B. P. M. \& Lučić, L. R. 1999: Onychiurus pancici, a new cave-dwelling endemic species from Serbia, Yugoslavia (Collembola: Onychiuridae). - Ent. Ber. 59 (1999): 190-191.

Deeleman-Reinhold, C. L. 1978: Revision of the cavedwelling and related spiders of the genus Troglohyphantes Joseph (Linyphiidae), with special reference to the Yugoslav species. - Acad. Sci. Art. Slov., Classis IV: Hist. Nat.; Opera 23; Inst. Biol. Ioannis Hadži, Ljubljana. 221 pp.

Fjellberg, A. 1998: The Collembola of Fennoscandia and Denmark. Part I: Poduromorpha. — Fauna Entomologica Scandinavica, Brill, Leiden. 184 pp.

Gisin, H. 1960: Collembolenfauna Europas. - Muséum d'Histoire Naturelle, Genève. 312 pp.

Hsï, K. 1972: When the Mediterranean dried up. - Scientific American 227: 25-36.

Hsï, K. 1978: When the Black Sea was drained. - Scientific American 238: 53-64.

Pomorski, R. J. 1990: New data on the genus Hymenaphorura (Collembola, Onychiuridae) from Europe. Mitt. Schweiz. Ent. Ges. 63: 209-225.

Pomorski, R. J. 1996: The first instar larvae of Onychiurinae - a systematic study (Collembola: Onychiuridae). - Genus 7: 1-102.

Pomorski, R. J. 1998: Onychiurinae of Poland (Collembola: Onychiuridae). - Polish Taxonomical Society, Wroclaw. $201 \mathrm{pp}$.

Pomorski, R. J. 2001: Review of the genus Hymenaphorura Bagnall, 1948 with description of eleven new species from North America and Siberia (Collembola: Onychiuridae). - Insect Syst. Evol. 32: 439- 474.

Weiner, W. M. 1996: Generic revision of Onychiurinae (Collembola: Onychiuridae) with cladistic analysis. - Ann. Soc. Entomol. Fr. (N. S.), 32: 163-200. 